\title{
ЗАГОЛОВОК НІМЕЦЬКОМОВНОЇ КОМЕРЦЙНОӦ ІНТЕРНЕТ-РЕКЛАМИ: МОВНІ ТА ПАРАЛІНГВАЛЬНІ ЗАСОБИ
}

Калинюк Т. В., Добринчук О. О.

\section{ВСТУП}

Значне місце у сфері сучасної масової комунікації посідає реклама, яка $€$ потужним засобом впливу на індивідуальну свідомість споживача.

Останніми роками реклама та ii складники стають об'єктом дослідження більшості лінгвістичних розвідок, що зумовлюється становленням у мовознавстві дискурсивної парадигми, яка вивчає способи взаємозв'язку когніції, комунікації, соціуму і мови. При цьому увагу мовознавців привертають мовні засоби впливу рекламного тексту на споживача. Зважаючи на те, що реклама - це явище динамічне, яке швидко «старіє», тому технології іiі впливу регулярно змінюються, поступово стають більш інноваційними, використовуючи при цьому різні засоби переконання. 3 огляду на це, реклама потребує грунтовного дослідження 3 погляду використання інноваційних мовних та позамовних засобів маніпулювання людською свідомістю.

Вивчення рекламного тексту на матеріалі різних мов відображено як у вітчизняних, так і в зарубіжних наукових розвідках у таких аспектах: загальнолінгвістичному (І.В. Городецька, Дж. Кук, О.В. Медведсва), лінгвостилістичному (М.M. Кохтєв, В.В. Самаріна, Т.А. Безугла), когнітивному (О.В. Іванців, В.І. Охріменко, О.С. Ткачук-Мірош-ниченко), соціолінгвістичному (Ю.В. Булик, І.О. Велика, Л.М. Крамаренко) та інші. Однак особливості використання мовних та паралінгвальних засобів у заголовку німецькомовної комерційної інтернет-реклами на прикладі проспектів не були предметом розгляду, що й визначає актуальність нашого дослідження.

У більшості лінгвістичних розвідок рекламу розглядають як рекламний текст, тобто особливий вид тексту, який $\epsilon$ одним 3 інструментів, що стимулює економічні процеси, має величезну силу психологічного впливу на суспільство Зміст поняття «реклама», на думку Т.А. Безуглої, можна узагальнити так: «1) реклама - це акт впливу, який може певною мірою визначати оцінний i практичний вибір чи залишати байдужим; 2) реклама - це ремесло i, відповідно, його продукт може бути оцінений як добра робота чи халтура; 3) реклама - це звернення до соціальних почуттів, маніпулювання 
цінностями, які можуть бути прийнятними для суспільства, навіть прогресивними або ж етично сумнівними; 4) реклама - це мистецтво і його твори можуть викликати захоплення чи відразу, бути оціненими як естетично досконалі чи посередні, а творці - як талановиті чи позбавлені доброго смаку» ${ }^{1}$.

\section{1. Структурно-композиційні компоненти рекламного тексту}

У наукових розвідках «реклама» розглядається як явище масової комунікації і визначається як «комплекс заходів, спрямованих на досягнення матеріального (здійснення покупки) або ідеального (зміна в системі поглядів) ефектів 3 метою формування i задоволення економічних, інформаційних і соціально-політичних запитів певної частини суспільства за допомогою різних засобів соціального зв'язку» ${ }^{2}$. Варто зазначити, що реклама $€$ об'єктом уваги дослідників креолізованих текстів, оскільки вона становить «одну з головних сфер, де за допомогою функціонуючих у єдиному графічному просторі зображення і слова вирішуються прагматичні завдання» ${ }^{3}$.

Рекламний текст характеризується типовістю структурнокомпозиційної організації, яка проявляється у схожій композиційній оформленості, тобто наявності певного набору структурних елементів тексту, організованих у певній послідовності, що характеризує рекламу як особливий тип тексту. Серед структурно-композиційних компонентів рекламного тексту як креолізованого лінгвісти виокремлюють мовні (вербальні) та паралінгвальні (невербальні).

Т.А. Безугла відносить до вербальних компонентів слоган/девіз/гасло, заголовок/зачин, підзаголовок/звернення, основний/поточний текст або інформаційний блок, коду/заключний заклик/друге гасло/ехофразу/кінцівку, утилітарну інформацію/адресу фірми/довідкові відомості. Серед невербальних компонентів вона розрізняє набірні (параграфемні синграфемні, суперграфемні й топографемні) і зображальні, останні включають зображення товару, візуальний контекст, логотип/фірмовий товарний знак/торгову марку/марку товару/назву фірми. Виокремлюється також вставка, яка може бути як вербальною, так і невербальною 4 .

1 Безугла Т.А. Англо- і німецькомовний рекламний дискурс: полікодовий лінгвопрагматичний підхід : дис. ... канд. філол. наук : 10.02.04. Харків, 2017. С. 29.

2 Никитина С.В. Национальная специфика текста промышленной рекламы (на материале русскоязычных и англоязычных периодических изданий по вычислительной технике) : дисс. ... канд. филол. наук : 10.02.19. Воронеж, 1998. С. 4.

${ }^{3}$ Махнин П.Н. Психолингвистические аспекты воздействия рекламных текстов : автореф. дисс. на соискание науч. степени канд. филол. наук : 10.02.19. Москва, 2005. $20 \mathrm{c}$.

4 Безугла Т.А. Англо- і німецькомовний рекламний дискурс: полікодовий лінгвопрагматичний підхід : дис. ... канд. філол. наук : 10.02.04. Харків, 2017. С. 57. 
Грунтуючись на дослідженнях Т.А. Безуглої та С.В. Нікітіної5, вербальні компоненти можна об'єднати у три структурно-семантичні блоки:

1) заголовковий комплекс (слоган, заголовок, підзаголовок, кода);

2) основна частина (основний текст);

3) реквізитна інформація про рекламодавця (утилітарна інформація). Вербальні компоненти розташовуються зазвичай відокремлено один від одного із застосуванням різних шрифтів та кольорів під основним зображенням або поряд із зображенням.

Рекламний слоган є найважливішою мовною складовою частиною рекламного тексту, це центральне висловлювання, яке завдяки своїй стислості та лаконічності посилює вплив на адресата, спрощуючи процес запам'ятовування інформації ${ }^{6}$. Саме слоган уможливлює підсвідоме рішення читача про те, чи буде він читати текст, чи ні ${ }^{7}$. Основними функціями слогану є: вплив на адресата, інформування, презентаційна (створення іміджу фірми), мнемонічна, оцінна, текстотвірна, коннективна, емоційно-апелятивна. Зазначені функції уможливлюють розгляд його як «відносно самостійного явища, як мікротекст зі своїм набором структурних, семантичних, стилістичних $\mathrm{i}$ прагматичних параметрів» ${ }^{8}$.

Заголовок - найважливіший компонент вербальної частини реклами. Його функції визначаються актуалізацією основного рекламного аргументу, привертанням уваги та зацікавленням реципієнта, ідентифікацією товару/послуги, що у кінцевому підсумку зумовлює його реалізацію. Заголовок розташований безпосередньо перед основним текстом та вводить його зміст. Зважаючи на те, що заголовки $\epsilon$ дуже стислими, вони демонструють розмаїття стилістичних прийомів і експресивних мовних засобів. Однак варто відрізняти заголовок від слогану. Слоган $\epsilon$ коротшим за заголовок і розташований ізольовано, головною диференційною ознакою слогану $є$ відображення загальної

5 Никитина С.В. Национальная специфика текста промышленной рекламы (на материале русскоязычных и англоязычных периодических изданий по вычислительной технике) : дисс. ... канд. филол. наук : 10.02.19. Воронеж, 1998. C. 106.

${ }^{6}$ Bezugla L. Arten von Implikaturen. Semantik und Pragmatik im Spannungsfeld der germanistischen und kontrastiven Linguistik. Frankfurt am Main : Peter Lang, 2013. S. 169-182.

7 Бондаренко О.М. Соціолінгвістичні аспекти перекладу рекламних текстів. Мова і культура. 2010. Вип. 13. Том ІІІ (139). С. 292-295.

8 Колокольцева Т.Н. Слоган как ключевой компонент рекламного текста. Рекламный дискурс и рекламный текст : коллективная монография. Москва : Флинта: Наука, 2013. С. 147. 
філософії фірми․․ Проте слоган може співпадати із заголовком або доповнювати його.

Підзаголовок - текст, який підкріплює заголовок і тему рекламного тексту, розвиває іiі, повідомляє конкретні факти, що може потребувати більшого обсягу слів, ніж у заголовку.

Основний текст містить всю інформацію про товар або послугу, є логічним продовженням заголовку i підзаголовків, розвиває аргументацію. Він, як правило, довший за заголовок, друкується меншим шрифтом і не привертає особливої уваги.

Кода - структурно-композиційний елемент, що містить спонукання до дії і розрахований на реакцію адресата у формі покупки, запиту додаткової інформації або дії ${ }^{10}$.

Утилітарна інформація спрямовує адресата у його діях: адреса магазину, форма запиту, номер телефону з безкоштовним зв'язком тощо, якщо він зацікавиться товаром і захоче його купити: Mehr Informationen auf www.MINI.de/clubman (авто Clubman Mini); Direkt unter schwaebisch-hall.de (будівельна страхова компанія Schwäbisch Hall).

Однак не всі рекламні тексти мають зазначені структурні елементи, тому це вільний тип тексту. Вважається, що, чим престижніший бренд, тим меншу роль відіграють у його рекламі вербальні компоненти 3 розрахунку на те, що потенційний адресат і так обізнаний з історією та статусом марки.

\section{2. Структурні та семантичні складники заголовка німецькомовного рекламного тексту}

Заголовок рекламного тексту відзначається змістовими та мовними особливостями, що визначає його найважливішим вербальним блоком. Завдяки індивідуальному та нетрадиційному характеру у мовному відношенні заголовок привертає увагу адресата. Тому, аналізуючи структурно-семантичні складники вербальних елементів сучасних німецькомовних рекламних текстів комерційної тематики, зосереджуємо увагу на цьому блоці. Матеріалом для вивчення $\epsilon$ заголовки рекламних текстів, що визначені методом суцільного добору 3 німецькомовних інтернет-видань рекламних проспектів, зокрема

\footnotetext{
${ }^{9}$ Кафтанджиев Х. Тексты печатной рекламы. Москва : Смысл, 1995. С. 5.

${ }_{10}$ Бове К.Л. Современная реклама. Тольятти : «Издательский Дом Довгань», 1995. C. 174.
} 


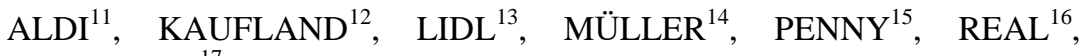
ROSSMANN ${ }^{17}$.

Щодо належності мови реклами до певного функціонального стилю, вважається, що мова реклами: а) тяжіє до публіцистичного стилю; б) репрезентує діловий стиль, оскільки сферою ії функціонування $\epsilon$ торгівля, яка є одним із різновидів ділових відношень; в) поєднує риси публіцистичного, науково-популярного $\mathrm{i}$ розмовного стилів ${ }^{18}$. Фактичний матеріал дослідження свідчить про доцільність останньої точки зору. Оскільки вербальний текст, будучи ієрархічно організованою системою, є результатом реалізації цілої низки кодів графічного, морфологічного, лексико-семантичного, ритмікометричного, синтаксичного тощо ${ }^{19}$.

Експресивний характер рекламного тексту зумовлює його насиченість експресивними засобами на всіх рівнях мовної організації - від фонетичного до синтаксичного ${ }^{20}$. Аналіз фактичного матеріалу, а також 3 урахуванням визначених Т.А. Безуглою фоностилістичних засобів рекламного заголовка виокремимо найбільш типові, такі як: рима, алітерація та параномазія.

Pима вважається найтиповішим фоностилістичним засобом у рекламному заголовку: Haribo macht Kinder froh und Erwachsene ebenso (солодощі Haribo); Sparprofis für Ihr Homeoffice (товари Aldi); Sackeweise KNÜLLERPREISE (продукти Domini). Менш частотним $є$ римування одних і тих самих частин мови: In der Sonne liegen statt zu Hause frieren (турагенство l'tur); Keine Experimente bei der Rente

11 Aldi Katalog: вебсайт. URL: https://catalog.aldi.com/emag/de_DE/print/ ALDI_SUED_Onlineprospekt_KW5119/html5.html\#52 (дата звернення: 10.04.2020).

${ }_{12}^{12}$ Kaufland Prospekt-Angebote: вебсайт. URL: http://onlineprospekt.com/kauflandprospekt-angebote-ab-12-12-19/\#more-27399 (дата звернення: 11.04.2020)

${ }_{3}$ Lidl Prospekt-Angebote: вебсайт. URL: http://onlineprospekt.com/lidl-prospektangebote-ab-16-12-19/\#more-27365 (дата звернення: 11.04.2020).

14 Müller Prospekt-Angebote: вебсайт. URL: http://onlineprospekt.com/muellerprospekt-angebote-ab-16-12-19/\#more-27427 (дата звернення: 14.04.2020).

15 Penny Prospekt-Angebote: вебсайт. URL: http://onlineprospekt.com/pennyprospekt-angebote-ab-16-12-19/\#more-27444 (дата звернення: 14.04.2020).

${ }_{16}$ Real Prospekt-Angebote: вебсайт. URL: http://onlineprospekt.com/real-prospekt angebote-ab-09-12-19/\#more-27348 (дата звернення: 16.04.2020).

${ }^{17}$ Rossmann Prospekt: вебсайт. URL: http://onlineprospekt.com/rossmann-prospektangebote-ab-02-12-19/ (дата звернення: 16.04.2020).

18 Кохтев Н.Н. Реклама: искусство слова. Рекомендации для составителей рекламных текстов. Москва : Изд-во МГУ, 1997. С. 66-68.

${ }^{19}$ Ворошилова М.Б. Политический креолизованный текст: ключи к прочтению : монография. Екатеринбург : Изд-во Уральского гос. пед. ун-та, 2013. С. 68.

20 Безугла Т.А. Англо- і німецькомовний рекламний дискурс: полікодовий лінгвопрагматичний підхід : дис. ... канд. філол. наук : 10.02.04. Харків, 2017. C. 114 . 
(фірма страхування Asstel). Рима застосовується частіше у поєднанні 3 ритмічною організацією висловлення: Für ein paar Scheine mobil an der Leine! (квиток GVH-Mobilcard); Basteln, tupfen, kleben - erweckt die Fantasie zum Leben! (товари Real) Найбільш естетично привабливою $\epsilon$ внутрішня рима у поєднанні із лексичним повтором: Flussmomente sind Genussmomente (турбюро AROSA).

Алітерація - повторення приголосних звуків, $є$ характерною для германської художньої традицій взагалі, про що свідчить значна кількість парних словосполучень 3 алітерацією і внутрішньою римою: Probieren. Pflegen. Perfekt aussehen (крем Vichy); Der aufregende Herbstlook: Feuer und Flamme (помада Margaret Astor); Deine frische Fische zum Fest (овочі і фрукти Lidl).

Парономазія (паронімічна атракція) - фігура мовлення, яка виражається у каламбурному використанні паронімів в образних або комічних цілях, наприклад: MEINE MODE - MADE BY MAMA!; Neuе Models treffen neue Modelle; innen innovativ. aussen aussergewöhnlich; Für Konfekt bin ich immer zu haben, aber nicht immer für Konfektion; Abholen \& App holen.

Використання фоностилістичних засобів підвищує експресивність рекламного тексту, стимулює зацікавленість адресата, має мнемонічний і сугестивний ефект, що слугує досягненню спонукальної цілі рекламодавця.

Лексико-семантичні та лексико-граматичні засоби у рекламному заголовку. Вважається, що лексика визначає основний потенціал рекламного тексту та заголовку зокрема, оскільки є вербальним носієм змісту.

На відміну від інших типів дискурсу, рекламний дискурс не має специфічної лексики, а використовує загальновживану лексику. За спектром вживання, модифікуючи дані О.В. Мєдвєдєвої, поділяємо лексичний склад німецькомовних рекламних заголовків на п'ять шарів:

1) загальновживані слова;

2) термінологія;

3) сленг і просторіччя;

4) оказіональні новоутворення;

5) варваризми ${ }^{21}$.

Перший, основний, пласт лексики рекламного заголовка становлять слова літературної мови, що включають службові та повнозначні слова. Використання займенників 2-ї особи du/dein, ihr/euer, а також 3-ї особи множини Sie/Ihr підсилює інтерактивний аспект рекламної

${ }^{21}$ Медведева Е.В. Рекламный текст как переводческая проблема. Вестник МГУ. Сер. 19: Лингвистика и межкультурная коммуникация. 2003. № 4. С. 30-32. 
комунікації, реалізуючи при цьому стратегію привертання уваги: Schreiben Sie? Wir veröffentlichen Ihr Manuskript. Використання займенників 1-ї особи ich/mein, wir/unser слугує встановленню контакту, вказуючи на адресанта: Ich sorge bei Ihnen zuhause für ein noch schnelleres Surferlebnis. Wir wollen, dass aus Ihnen etwas Besonderes wird.

Проаналізувавши заголовки рекламних текстів, зазначимо, що серед іменників цього шару найчастотнішими $є$ такі семантичні групи:

1) назви предметів побуту (меблі, одежа тощо), які пов'язані 3 рекламованими товарами: die Schuhe, die Uhr, das Haus, das Auto, der Koffer, der Teppich, der Wäschetrockner, die Mascara, der Gürtel, die Bahncard тощо;

2) назви частин тіла людини: die Hände, der Rücken, die Beine, das Herz, die Haut, die Lippen, der Hals тощо;

3) назви продуктів харчування: die Milch, die Rohmilch, das Bier, die Sahne, der Tee, die Sauce, das Brot, die Äpfel, das Gebäck, die Pralinen, die Torte тощо;

4) лексеми, що позначають поняття, пов'язані із життєдіяльністю людини: die Familie, das Leben, der Geburtstag, der Feiertag, der Alltag, der Haushalt, die Wohnung, die Zeit, das Geld, die Geschichte, der Urlaub, die Reise тощо;

5) абстрактні поняття: das Gefühl, die Liebe, der Komfort, der Geschmack, die Freiheit, die Aussichten тощо;

6) власні назви (географічні назви, імена загальновідомих історичних постатей, VIP-персон, назви літературних творів та персонажів) Europa, Deutschland, Österreich, die Schweiz, Köln, Berlin, Wien, Tirol, Australien, England, Bayern, Tel Aviv, der Rhein, Leonardo тощо.

Семантика дієслів пов'язана із життєдіяльністю людини - побутом, вподобаннями, почуттями, професійною діяльністю тощо: einschlafen, leben, fühlen, schenken, schmecken, auswählen, sehen, heißen, kaufen,einkaufen, backen, fahren, erzählen. Частотними є дієслова зі значенням відкриття нових речей і властивостей: entdecken, erleben, eröffnen, den Horizont erweitern, lernen, bedenken, nachdenken, neu denken. Трапляються і модальні дієслова, наприклад: WORAUF SIE ACHTEN SOLLTEN, WENN SIE DEN BESTEN TEPPICH DER WELT WOLLEN (текстиль Müller). Frauen wollen schöne Beine (крем Kamille). EMPFINDLICHE AUGEN: Noch nie konnten Ihre Augen einem Mascara so trauen (туш Mascara).

Другий шар лексики становить спеціальна термінологія, пов'язана 3 типом товару, що рекламується, і є типовою для сфери господарської діяльності людини (техніка, парфюмерно-косметична промисловість, індустрія моди). Використання термінології в рекламних текстах 
здебільшого зумовлене прагненням рекламістів надати їм більшої достовірності.

Третій шар лексики рекламних заголовків становлять сленги та просторіччя. Їх вживання зумовлене необхідністю висловлення експресивності, привернення уваги цільової аудиторії, наприклад: Deutschlands coolste Learning Agentur stammt aus Wien (студія дизайну); Ablegen. Abfeiern. Abdreißig. (вечірка Rheinschff-Party ab 30); Nur BioFrüchte + Quellwasser. Sonst nix! (напій Bio-Schorly).

Четвертий шар лексики становлять оказіональні новоутворення, до яких відносимо як семантичні, так і модельовані оказіоналізми, функція яких полягає у створенні образності та наданні лаконічності висловлюванню, наприклад: aldi|gen (супермаркети Aldi). Популярним $\epsilon$ прийом новоутворення-каламбур: Fröhliche Zweihnachten! (компанія Samsung); Frohe Dreinachten! (видавництво Fischer); Urglaublich, aber nah! (зоопарк Zoo); $O$ du fröhliches Notebook: Mit dem Acer Aspire 5 werden Wünsche wahr (компанія Assus); Lust auf NESPRESSO Kaffee (кава Espresso); PANTENE PRO-V: starke Oktoberfest Zöpfe (шампунь); Tausendsassa: Ssssst... die richtige Dosis Haarspray, und die Frisur sitzt (лак для волосся ISANA); Jubel-Preis am Framstag (проспект товарів Penny).

У заголовках трапляються багатоскладні оказіональні композити: Mein Für-die-liebsten-nur-das-beste-Packet (доставка DHL); Aus Weitweg-Sein wird Nah-dran-Bleiben (журнал Kölnische Rundschau); Aus Genau-Hinschauen wird Groß-Rauskommen (журнал Kölnische Rundschau). Їх вживання зумовлене прагненням економії місця.

П'ятий шар лексики представлений варваризмами неасимільованими запозиченнями. Як вказує В.В. Зірка, рекламодавці користуються «дохідливим лексиконом», який формується, по-перше, запозиченнями, по-друге, «новомодними словами» ${ }^{22}$. Серед варваризмів переважають англійські слова: das Halloween, das Ketchup, der Handicap, der/die Fitness, der Control, das Team, der Job, das Ticket, die Airline, die Shoes, die Lounge (холл), das Partnerlook тощо.

Англоамериканізми в рекламному заголовку виконують такі функції:

- інформативну - номінують нові явища та предмети різних сфер, потрапляючи в рекламу із фахової термінології: das Smatphone, die Flatrate, die Repair, die Energy;

- створення фахового колориту, здебільшого у рекламі комп'ютерів: die IT, der Flat;

2 Зирка В.В. Современная реклама: манипуляции с «модными словами». Лінгвістика ХХІ століття: нові дослідження і перспективи. 2009. № 3. С. 116-120. 
- експресивну - для посилення оцінного значення та виокремлення з потоку окремих характеристик товару: Wow! Clever; das Happy End.

Друге місце у заголовках серед запозичень посідають французькі: LA FEMME PRADA/L'HOMME PRADA (парфюми Prada); Besetzt bei den Damen, frei bei den Herren. Salut, Monsieur! Vive le Moment (цигарки Gauloises).

Зауважимо, що систематизований матеріал дослідження підтверджує загальновизнану експресивність рекламного тексту: «Емоційність реклами створює у споживача мимовільний ефект довіри» ${ }^{23}$, яка $є$ дуже важливою задля досягнення цілей рекламодавця.

Аналіз фактичного матеріалу засвідчив, що експресивність у заголовках рекламного тексту створюється такими лексикограматичними засобами, як: експресивно-оцінна лексика, ступені порівняння прикметників та якісних прислівників, лексичні повтори, квантори винятковості, універсалізації та загальності, інтенсифікатори, фразеологізми.

Експресивно-оцінна лексика виконує функцію нав'язування позитивної оцінки. Оцінні слова можуть бути раціональними (effektiv, wirksam, ökologisch, sich lohnen, kraftvoll, genügen, der Unterschied, die Alternative, maximum, minimal, ultimate) i емоційними (toll, duft, wunderbar, hervorragend, herrlich, großartig, am schönsten, happy, extra, legendary). Більшість оцінних слів - прикметники, це пояснюється їх семантичними властивостями - пояснення, характеристика предметів. Нами виокремлено такі оцінні слова, які вживаються у заголовках рекламних текстів:

- прикметники і прислівники gut, günstig, flexibel, perfekt, schön, effektiv, erfolgreich, innovativ, ausgezeichnet, glücklich, leise, fein, kreativ, attraktiv, ideal, fine, good, excellent, nice, original, small, big, great, real;

- дієслова sich wundern, faszinieren, erleben, sich beeindrucken lassen, sich freuen, genießen, feiern, auffallen;

- іменники die Faszination, das Vergnügen, die Schönheit, die Spitzen, die Innovation, der Eleganz, der Luxus, der Spaß, die Freude, der Genuss, die Lust, die Liebe, Premium-Qualität.

Серед експресивно-оцінної лексики виділяються так звані «ударні» $\mathrm{i}$ «магічні» слова і вирази ${ }^{24}$ :

${ }^{23}$ Шестак Л.A. Life style: речевые стратегии коммерческой рекламы. Рекламный дискурс и рекламный текст : коллективная монография. Москва : Флинта : Наука, 2013. C. 62.

24 Павлюк Л.Г. Аксіологічні та структурні характеристики дискурсу реклами у мас-медіа. URL: http://journlib.univ.kiev.ua/index.php?act=article\&article=1460 (дата звернення: 12.04.2020). 
a) «ударні» слова мають значення гіперболізації, найвищого вияву емоцій (glücklich machen, himmlisch, begeistern, außergewöhnlich) große Ideale; zauberhafter Winterspaß; erster Platz; das Meisterstück; MEGA\% Make up WOCHE; Aabsolute Freiheit;

б) «магічні» слова - слова-обіцянки (das Geschenk, der Rabatt, die Überraschung, das Sonderangebot, das Schnäppchen, der Ausgabeaufschlag, ohne Konto-Gebühren, Zinsen) - -50\%, Ihr Partner, die Fürsorge, gratis, garantiert, gewinnen, helfen, sparen; Bis zu 20\% mehr Guthaben!, 50\% billiger, bis zu 75\% Preisvorteil! 2 × mal SPAREN, jetzt richtig selbst beschenken, 3 nehmen 2 zahlen.

Частотним є вживання різних типів лексичного повтору:

- контактний: Ja, und was bitte bleibt, wenn die Feierlichkeiten zu Ende sind? Karrieren, Karrieren, Karrieren (L'Oréal);

- анафора - повтор початкових частин лексичних одиниць: Meine Auswahl, Meine Sicherheit, Meine 10\% Rabatt (товари Kaufland); Besser Shoppen. Besser Fühlen. (товари Lidl); Mein Bad. Mein Spa. Mein Moment. (косметика Rossmann).

- епіфора - повтор кінцевих частин слова: Ist gut, schmeckt gut (печиво Leibniz); Die пеие burda easy ist da! (одяг Burda); Geht nicht, gibt's hier nicht (одяг Adidas); Ruck, zuck, weg (товари Rossmann);

- кільце - повтор на початку і наприкінці мовленнєвої одиниці: I am what I am (одяг та взуття Reebok), WOMEN $\underline{M E N}$; Einmal hin. Alles drin. (каталог Real.de).

Вживання прикметників та якісних прислівників у ступенях порівняння: Die schnellste Gardine der Welt (гардина Hарру Home); Warm, wärmer, noch wärmer... (туроператор Schauinsland Reise); Die weltweit beste Kamera in einem Smartphone (телефон Sony Xperia Z5); Tollste Mode für eisige Tage (одяг Burda); Der schnellste GTi aller Zeiten (авто Peugeot 308 GTi); Lecker, leckerer, Levante! (олія enerBiO).

Поширеними $є$ також семантичні суперлативи, які здебільшого виражені композитами: Bärenstark! Schnell gegen Schmerzen. Alles, was Sie von einem Schmerzmittel erwarten! (пігулки Optalidon); Der Spitzenkäse aus Italien (cиp Grana Padano); Superhit für TOMB RAIDER Fans: Schreiben mit Lara Croft (комп'ютерні ігри WATERMAN); Wundschutz wird jetzt kinderleicht (дитячий крем PENATEN Baby Wundschutz-Komplex).

Квантори винятковості, універсалізації та загальності (alle, nur, jeder, immer, nie, niemals, ganz, einzig, always тощо) сприяють реалізації стратегії аргументації: Alles, was Lippen brauchen (бальзам для губ Blistex); Alles für Deinen Sport! (магазин спорттоварів Badminton Ulrich); Dein anzigartiger Lindl-Löfel (товари Lindl); Wir haben ein Herz für jeden Apfel... 
Інтенсифікатори (засоби, які виражають категорію інтенсивності, пов'язану з поняттями міри кількості або величини якості) охоплюють підсилювальні та модальні частки (einfach, nur, mal, ja, überhaupt тощо): Einfach günstig fahren (авто Volkswagen); Nur diese Woche Weihnachtsrabatt auf diese Ferrero-Produkte (солодощі Fererro).

Фразеологізм теж посилює ступінь експресивності заголовка Lights in Hülle und Fülle (цигарки Lucky Strike Lights); Happy Helloween! So verwandelt ihr euch Schritt für Schritt in einen Vampir (декоративна косметика L'Oreal), Glanz \& Gloria (футболки Prada), Wer die Wahl hat, hat die Qual: klassisch elegant oder traditionell rustikal (продукти Lidl); KLEIN \& FEIN (Giorgio Armani); GROSS \& KLEIN IM PARTNERLOOK (товари Müller).

Таким чином, до структурно-семантичних особливостей заголовка рекламного тексту відносимо: використання фоностилістичних засобів (риму, алітерацію, асонанс, парономазію). Лексика німецькомовного заголовка охоплює п'ять шарів:

1) слова загальнолітературної мови, що вживаються у прийнятому значенні в текстах усіх функціональних стилів;

2) спеціальну термінологію, пов'язану з рекламованим товаром;

3) сленгову й просторічну лексику;

4) оказіональні новоутворення;

5) варваризми, серед яких переважають англо-американізми.

До найважливішої характеристики заголовка відносимо експресивність, яка створюється такими лексико-граматичними засобами, як експресивно-оцінна лексика, прикметники та якісні прислівники у ступенях порівняння, лексичні повтори, квантори винятковості та універсалізації, інтенсифікатори, фразеологізми.

\section{3. Паралінгвальні компоненти у заголовках німецькомовної реклами}

Дослідження заголовків рекламного тексту не може обмежуватися аналізом виключно лише мовного наповнення. Рекламний текст - це багатокомпонентне утворення, продуктивність якого визначається особливістю взаємодії його мовних та паралінгвальних складників. Запорукою створення ефективного рекламного тексту $є$ правильно розподілена інформація між текстом і паралінгвальним компонентом.

Аналіз фактичного матеріалу засвідчив, що паралінгвальні засоби впливу представлені графічними та візуальними засобами. Їх вибір залежить від низки чинників: цільової аудиторії, цілей, особливостей рекламованого продукту.

До графічних засобів впливу відносимо прийоми шрифтового варіювання. Підкреслення фрагмента повідомлення, який несе важливу 
інформацію, дає змогу передати ключовий зміст, який не виражений вербально, формуючи при цьому позитивний настрій адресата. Шрифт слугує «оболонкою» оформлення усного мовлення i водночас $\epsilon$ ефективним засобом маніпуляції цільовою аудиторією. Правильне використання шрифтів забезпечує легку читабельність, асоціативність тексту, якісне сприйняття інформації та ії швидке запам'ятовування.

Продуктивним типом шрифтового варіювання $є$ капіталізаиія, тобто використання великих літер. Цей графічний засіб використовується для: підкреслення назви моделі рекламованого товару; відбиття назви компанії або інституції; демонстрації назви бренду; відбиття окремих літер, що слугує засобом зацікавлення, інтригування адресата.

Корпоративний імідж компанії створюється за допомогою особливого шрифту, який використовується лише цим брендом. Прикладом використання засобу капіталізації $є$ назви світових брендів (рис. 1).

\section{4uㅜㅇs JOOP!}

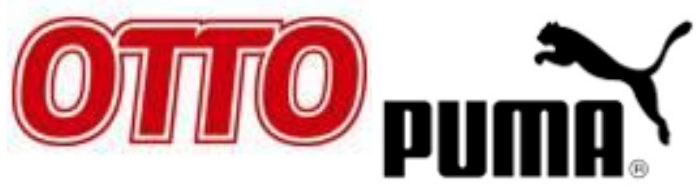

SALAMANDER ${ }^{\text {(i⿱ }}$

\section{Рис. 1. Використання засобу капіталізації у назвах світових брендів}

Прийом шрифтового варіювання передбачає також використання шрифту різного розміру, що сприяє ефективнішій графічній презентації товару, оптимізації процесу запам'ятовування. Розмір шрифту у заголовка залежить від важливості інформації, до якої він застосований. Це можна прослідкувати на прикладі реклами LACALUT, де елементи для запам'ятовування, а саме лексеми SCHÜTZT, STRAFT, позначені більшим шрифтом (рис. 2). 


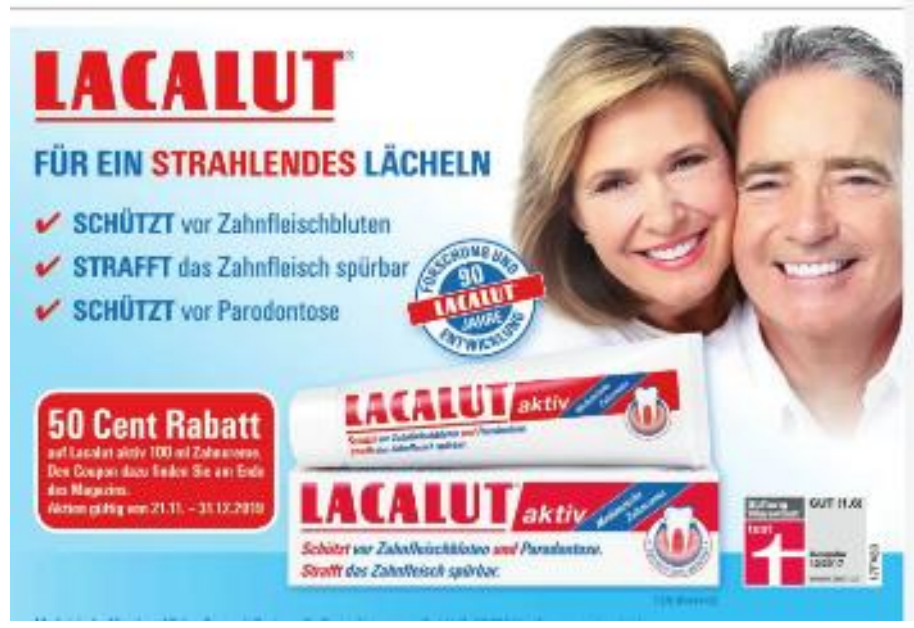

Рис. 2. Зразок рекламного тексту зі шрифтовим варіюванням

Окрім шрифтового варіювання, варто виділити й інші графічні засоби впливу у заголовках рекламних текстів:

1) вживання кількох однакових літер для передачі звуку: Ahaаa Diese Lippenstiftfarbe lieben Männer an uns Frauen! (помада Maybelline); Ho! Ho! Ho! Mehr Weihnachten für weniger Taler (журнал Euroshopp);

2) використання перших літер замість повного слова: $B \ldots A . . D \ldots /$ Besser als Dein;

3) використання параграфемних елементів: грошових символів $\$ \$$ (сприяють формуванню у свідомості адресата стійких асоціацій добробуту і прибутку), комп'ютерних знаків \#\#\# (\# Zurück zи schönет Haar; Genieße deinen \# freimoment!); делетаиї̈/закреслення I DON'T $C A R E$ (навмисне акцентування уваги на закресленому слові); іконічних елементів («вбудовані піктограми») WE $\vee$ APPLE (компанія Adobe); цифр ICH SEHE W4S, WAS DU NICHT SI3HST. (Institut der Wirtschaftsprüfer IDW).

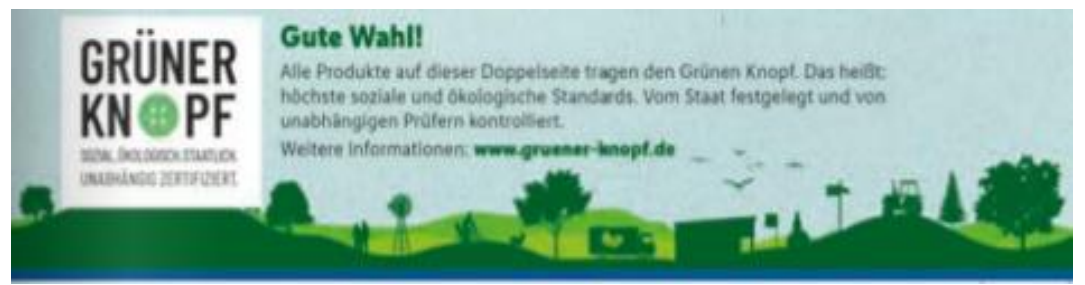

Рис. 3. Зразок використання в рекламному заголовку графічного елемента 
До найефективніших засобів візуального впливу у заголовках реклами відносимо кольорове оформлення та зображувальні елементи, які здійснюють психологічний вплив на клієнта, $\epsilon$ маркером асоціативної інформації. Використання колористичного оформлення забезпечує привернення уваги до предмета рекламування, асоціативне запам'ятовування продукту. Однак нині у сфері реклами простежується широке використання чорно-білої реклами як можливості візуально виділити послугу чи товар.

На думку маркетологів, кожен колір має окремі асоціації, знання яких підвищить ефективність рекламованого товару, зокрема:

- синій/блакитний колір асоціюється зі спокоєм, стабільністю, мрійливістю, довірою;

- зелений колір пасує найбільше для зрілих та професійних брендів, які надають перевагу використанню природних, біоматеріалів;

- фіолетовий колір має таємничий характер, який здебільшого асоціюється з фантастикою, інтригою, містикою;

- червоний - це гарячий, збуджуючий колір, який, як правило, символізує пристрасть, енергію, кохання, тепло, вогонь, небезпеку;

- помаранчевий колір використовують для позначення радості та задоволення, молодості та гумору, а також у період міжсезоння особливо перехід від літа до осені;

- жовтий колір позначає, 3 одного боку, оптимізм і радість, 3 іншого - небезпеку;

- рожевий колір пасує для дівчат так само, як блакитний - для хлопців, тому в окремих випадках рожевий має відштовхувальний ефект для чоловіків. Цей колір асоціюється з ніжністю, романтичністю та оптимізмом. Найчастіше рожевий використовується у рекламі кондитерських виробів;

- сірий колір позначає професіоналізм, водночас чорний мужність та елегантність, сексуальність та силу;

- білий колір символізує свіжість, недоторканість, чистоту;

- коричневий - це колір, що символізує надійність, мужність, природність, тепло ${ }^{25}$.

Таким чином, використання параграфемних (графічних та візуальних) засобів у заголовках німецькомовної реклами забезпечує іiі популярність серед споживачів.

25 Diese Wirkung haben Farben in Marketing und Werbung: вебсайт. URL: https://99designs.de/blog/design-tipps/farben-marketing-werbung/. 


\section{ВИСНОВКИ}

У проведеному дослідженні проаналізовано специфіку використання мовних та паралінгвальних засобів у заголовку німецькомовного рекламного дискурсу інтернет-проспектів.

Узагальнено, що рекламний текст характеризується типовістю структурно-композиційної організації, яка проявляється у наявності трьох структурно-семантичних блоків: 1) заголовкового комплексу; 2) основного тексту; 3) реквізитної інформації про рекламодавця (утилітарної інформації).

Виявлено, що поєднання мовних та паралінгвальних засобів у рекламному заголовку забезпечує реалізацію основних його функцій: імперативної, естетичної, експресивної, метамовної тощо.

Систематизовано структурні та семантичні особливості німецькомовного рекламного заголовка на фонетичному, лексичному та граматичному рівнях мовної системи. Серед фоностилістичних засобів визначено: риму, алітерацію, асонанс та парономазію. Лексика німецькомовних рекламних заголовків охоплює п'ять пластів, такі як: 1) слова літературної мови; 2) спеціальна термінологія, пов'язана 3 рекламованим товаром; 3) сленг і просторіччя; 4) оказіональні новоутворення; 5) варваризми, серед яких переважають англоамериканізми. Характерною рисою лексики у заголовках $\epsilon$ iii експресивність, що виражається у вживанні ступенів порівняння прикметників, експресивно-оцінної лексики, слів-інтенсифікаторів, кваторів винятковості та універсалізації. Узагальнено, що вдало використані мовні засоби у рекламному заголовка здатні підвищити його експресивність, забезпечити посилення впливу на споживачів.

Охарактеризовано шляхи використання паралінгвальних компонентів у заголовках рекламних текстів, серед яких виокремлено графічні та візуальні.

Перспективи дослідження стосуються поглибленого аналізу німецькомовного рекламного дискурсу в площині взаємодії вербальних i невербальних компонентів рекламного тексту, із залученням лінгвокультурологічного підходу.

\section{АНОТАЦІЯ}

Стаття присвячена дослідженню особливостей використання мовних та паралінгвальних засобів у заголовках німецькомовного рекламного дискурсу інтернет-проспектів. Узагальнено структурні характеристики реклами як медіажанру, систематизовано структурно-семантичні особливості німецькомовного рекламного заголовка на різних рівнях мовної системи. 3'ясовано, що німецькомовний рекламний заголовок характеризується певними особливостями на фонетичному та лексичному рівнях мовної системи. Серед фоностилістичних засобів визначено риму, 
алітерацію, асонанс та парономазію. Лексика німецькомовних рекламних заголовків охоплює слова літературної мови; спеціальну термінологію, яка пов'язана 3 рекламованим товаром; сленг і просторіччя; оказіональні новоутворення; варваризми, серед яких переважають англо-американізми. Серед паралінгвальних компонентів у заголовках рекламних текстів виокремлено графічні та візуальні, які відіграють важливу роль у сприйнятті реклами споживачами та забезпечують іï популярність.

\section{ЛІТЕРАТУРА}

1. Безугла Т.А. Англо- i німецькомовний рекламний дискурс: полікодовий лінгвопрагматичний підхід : дис. ... канд. філол. наук : 10.02.04. Харків, 2017. 304 с.

2. Бове К.Л. Современная реклама. Тольятти : «Издательский Дом Довгань», 1995. 704 с.

3. Бондаренко О.М. Соціолінгвістичні аспекти перекладу рекламних текстів. Мова і культура. 2010. Вип. 13. Том III (139). C. 292-295.

4. Ворошилова М.Б. Политический креолизованный текст: ключи к прочтению : монография. Екатеринбург : Изд-во Уральского гос. пед. ун-та, 2013. $194 \mathrm{c.}$

5. Зирка В.В. Современная реклама: манипуляции с «модными словами». Лінгвістика ХХІ століття: нові дослідження і перспективи. 2009. № 3. C. 116-120.

6. Кафтанджиев X. Тексты печатной рекламы. Москва : Смысл, 1995. $128 \mathrm{c}$.

7. Колокольцева Т.Н. Слоган как ключевой компонент рекламного текста. Рекламный дискурс и рекламный текст : коллективная монография. Москва : Флинта: Наука, 2013. С. 147-171.

8. Кохтев Н.Н. Реклама: искусство слова. Рекомендации для составителей рекламных текстов. Москва : Изд-во МГУ, 1997. 96 с.

9. Махнин П.Н. Психолингвистические аспекты воздействия рекламных текстов : автореф. дисс. на соискание науч. степени канд. филол. наук : 10.02.19. Москва, 2005. 20 с.

10. Медведева Е.В. Рекламный текст как переводческая проблема. Вестник МГУ. Сер. 19: Лингвистика и межкультурная коммуникация. 2003. № 4. C. 22-44.

11. Никитина С.В. Национальная специфика текста промышленной рекламы (на материале русскоязычных и англоязычных периодических изданий по вычислительной технике) : дисс. ... канд. филол. наук : 10.02.19. Воронеж, 1998. 174 с.

12. Павлюк Л.Г. Аксіологічні та структурні характеристики дискурсу реклами у мас-медіа. URL: http://journlib.univ.kiev.ua/ index.php?act=article\&article=1460 (дата звернення: 12.04.2020). 
13. Шестак Л.A. Life style: речевые стратегии коммерческой рекламы. Рекламный дискурс и рекламный текст : коллективная монография. Москва : Флинта : Наука, 2013. С. 57-87.

14. Aldi Katalog: вебсайт. URL: https://catalog.aldi.com/emag/de_DE/ print/ALDI_SUED_Onlineprospekt_KW5119/html5.html\#52 (дата звернення: 10.04.2020).

15. Bezugla L. Arten von Implikaturen. Semantik und Pragmatik im Spannungsfeld der germanistischen und kontrastiven Linguistik. Frankfurt am Main : Peter Lang, 2013. S. 169-182.

16. Diese Wirkung haben Farben in Marketing und Werbung: вебсайт. URL: https://99designs.de/blog/design-tipps/farben-marketing-werbung/ (дата звернення: 20.04.2020).

17. Kaufland Prospekt-Angebote: вебсайт. URL: http://onlineprospekt.com/ kaufland-prospekt-angebote-ab-12-12-19/\#more-27399 (дата звернення: 11.04.2020).

18. Lidl Prospekt-Angebote: вебсайт. URL: http://onlineprospekt.com/ lidl-prospekt-angebote-ab-16-12-19/\#more-27365 (дата звернення: 11.04.2020).

19. Müller Prospekt-Angebote: вебсайт. URL: http://onlineprospekt.com/ mueller-prospekt-angebote-ab-16-12-19/\#more-27427 (дата звернення: 14.04.2020).

20. Penny Prospekt-Angebote: вебсайт. URL: http://onlineprospekt.com/ penny-prospekt-angebote-ab-16-12-19/\#more-27444 (дата звернення: 14.04.2020).

21. Real Prospekt-Angebote: вебсайт. URL: http://onlineprospekt.com/ real-prospekt angebote-ab-09-12-19/\#more-27348 (дата звернення: 16.04.2020).

22. Rossmann Prospekt: вебсайт. URL: http://onlineprospekt.com/ rossmann-prospekt-angebote-ab-02-12-19/(дата звернення: 16.04.2020).

Information about the authors: Kalyniuk T. V.,

Candidate of Pedagogic Sciences, Head of the Department of German Kamianets-Podilskyi Ivan Ohiienko National University 61, Ohiienko str., Kamianets-Podilskyi, 32301, Ukraine

Dobrynchuk O. O.,

Candidate of Philological Sciences, Associate Professor at the Department of German Kamianets-Podilskyi Ivan Ohiienko National University 61, Ohiienko str., Kamianets-Podilskyi, 32301, Ukraine 